calculation for each term and their sum which contribute to $\Delta G$ are reported in Table II. In any case, the entropy of the reactions is unfavorable and particularly for photoreduction in $\mathrm{CO}$.

The enthalpy, $\Delta H$, is calculated in Table III from the energy balance of the bonds created and destroyed in reactions 13-16. The $\mathrm{Ni}-\mathrm{O}$ and $\mathrm{Ni}-\mathrm{CO}$ bond energies are taken as 24 and $30 \mathrm{kcal}$ $\mathrm{mol}^{-1}$ from theoretical calculation where $\mathrm{Ni}$ is in a zerovalent state. ${ }^{47}$ These values are not known for $\mathrm{Ni}^{2+}$ and $\mathrm{Ni}^{+}$ions, but one can expect that the difference of the bond energies does not change drastically with the oxidation state of nickel. The $\mathrm{Ni}^{+}-\mathrm{H}_{2}$ bond energy is evaluated to be $8.5 \mathrm{kcal} \mathrm{mol},{ }^{132}$ and the $\mathrm{O}-\mathrm{H}$ and $\mathrm{O}-\mathrm{C}$ bond energies are taken from the literature. ${ }^{55}$ In conclusion, whatever the pressure (reactions 13-15) and the nature (reactions 15 and 16) of the gas, the photoreduction is thermodynamically highly favorable since $\Delta G$ ranges from -116.5 to $-146 \mathrm{kcal} \mathrm{mol}^{-1}$.

Registry No. $\mathrm{Ni}^{2+}, 14701-22-5 ; \mathrm{SiO}_{2}, 7631-86-9 ; \mathrm{Ni}^{+}, 14903-34-5$; $\mathrm{H}_{2}$, 1333-74-0; $\mathrm{CO}, 630-08-0 ; \mathrm{Ni}, 7440-02-0$.

(55) Huheey, J. E. Inorganic Chemistry; Harper \& Row: New York,

\title{
Mechanism of the Reaction of Nitric Oxide, Ammonia, and Oxygen over Vanadia Catalysts. 1. The Role of Oxygen Studied by Way of Isotopic Transients under Dilute Conditions
}

\author{
Frans J. J. G. Janssen, * Frans M. G. van den Kerkhof, \\ Department of Chemical Research, Research and Development Division, Arnhem Institutions of the Dutch \\ Electricity Utilities, NV KEMA, 6800 ET Arnhem, The Netherlands
}

Hans Bosch, and Julian R. H. Ross

Department of Chemical Technology, Twente University of Technology, 7500 AE Enschede, The Netherlands (Received: October 14, 1986)

\begin{abstract}
The mechanism of the selective reduction of nitric oxide with ammonia in the presence of labeled oxygen has been investigated over a series of catalysts consisting of unsupported $\mathrm{V}_{2} \mathrm{O}_{5}, \mathrm{~V}_{2} \mathrm{O}_{5}$ on $\mathrm{TiO}_{2}, \mathrm{~V}_{2} \mathrm{O}_{5}$ on $\mathrm{SiO}_{2} / \mathrm{Al}_{2} \mathrm{O}_{3}$, and $\mathrm{V}_{2} \mathrm{O}_{5}$ on $\mathrm{Al}_{2} \mathrm{O}_{3}$. The results confirm that lattice oxygen participates in the reaction. It is shown that this participation can be explained in terms of a reduction/oxidation mechanism. Water, produced as a result of the reaction involving $\mathrm{NO}, \mathrm{NH}_{3}$, and $\mathrm{O}_{2}$, is formed at two sites; the first part comes from the reaction of gaseous nitric oxide and adsorbed ammonia via an Eley-Rideal mechanism and the other comes from a surface dehydration process. The experimental findings are explained by a slightly modified and extended version of a mechanism proposed earlier.
\end{abstract}

\section{Introduction}

There is an increasing demand in Western Europe for a reduction in the level of $\mathrm{NO}_{x}$ emissions $(x=1,2)$ coming from man-made sources. Such emissions are blamed for the production of "acid rain" and for other environmental problems. Selective catalytic reduction is one of the possible options for postcombustion control of emissions from stationary sources (i.e., power stations). ${ }^{\text {la }}$ Ammonia has been found to be a selective reducing agent for $\mathrm{NO}_{x}$. Selective reduction is necessary because of the presence in most flue gases of oxygen (1-5\%), which would react with unselective reducing agents such as carbon monoxide and alkanes. It has been shown that the selective reduction of $\mathrm{NO}_{x}$ by ammonia occurs more rapidly in the presence of oxygen than in its absence and that oxygen participates in the reaction; $;^{1-4}$ it has been found that the influence of oxygen during reduction experiments is considerable even when its concentration is below $1 \%$ in volume.

Most of the mechanistic work done on the system $\mathrm{NO} / \mathrm{NH}_{3}$ has excluded the presence of oxygen; therefore, very little is known as yet about the behavior of oxygen during the reduction of NO with $\mathrm{NH}_{3}{ }^{5-12}$ In addition, the exchangeability of oxygen with

(1) (a) Janssen, F. J. J. G.; van den Kerkhof, F. M. G. Kema Sci. Tech. Rep. 1985, 3, 71. (b) Janssen, F. J. J. G. Thesis, Twente University, 1987.

(2) Bauerle, G. L.; Wu, S. C.; Nobe, K. Ind. Eng. Chem. Prod. Res. Dev. 1975, 14,268 .

(3) Inomata, M.; Miyamoto, A.; Murakami, Y. J. Catal. 1980, 62, 140.

(4) Shikada, T.; Fujimoto, K.; Kunugi, T.; Tominaga, H.; Kaneko, S.; Kubo, Y. Ind. Eng. Chem. Prod. Res. Dev. 1981, 20, 91.

(5) Miyamoto, A.; Kobayashi, K.; Inomata, M.; Murakami, Y. J. Phys. Chem. 1982, 86, 2945.

(6) Hardee, J. R.; Hightower, J. W. J. Catal. 1984, 86, 137.

(7) Mizumoto, M.; Yamazoe, N.; Seiyama, T. J. Catal. 1978, 55, 119.
TABLE I: Catalysts Used in This Study

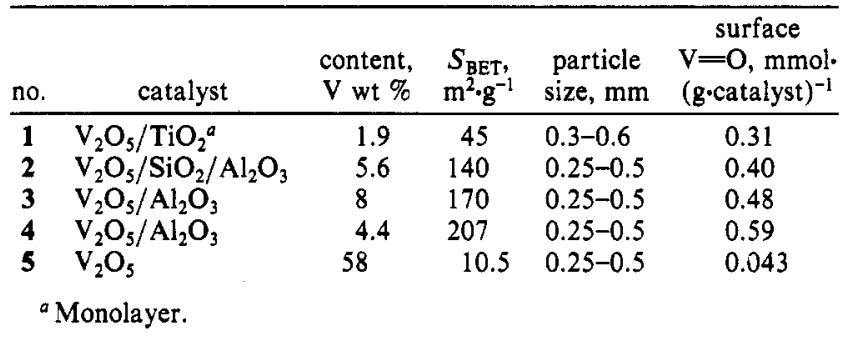

supported catalysts has received little attention. The only article of which we are aware describes the effect of labeled oxygen $\left({ }^{18} \mathrm{O}_{2}\right.$ throughout) on the reduction of NO over copper vanadate; these experiments were carried out in a low-pressure gas-circulation reactor system. ${ }^{13}$

In a previous paper ${ }^{14}$ we described experiments in which monolayer and commercial catalysts were compared using two types of experimental systems, that of the continuous flow type and that of the pulse type. It was found that at least two types of active site were present on the surface of the catalyst and that

(8) Williamson, W. B.; Lunsford, J. H. J. Phys. Chem. 1976, 80, 2664.

(9) Niiyama, H.; Murata, K.; Echigoya, E. J. Catal. 1977, 48, 201. 308 .

(11) Otto, K.; Shelef, M. J. Phys. Chem. 1972, 76, 37.

(12) Otto, K.; Shelef, M.; Kummer, J. T. J. Phys. Chem. 1970, 74, 2690.

(13) Yoshida, S.; Ueda, A.; Tarama, K. Ind. Eng. Chem. Prod. Res. Dev. 1979, 18, 283.

(14) Bosch, H.; Janssen, F.; van den Kerkhof, F.; Oldenziel, J.; van Ommen, J. G.; Ross, J. H. R. Appl. Catal. 1986, 25, 239. 
these sites are probably due to the presence of vanadium species with valences of both +4 and +5 . Two different reactions occur on these different sites: the oxidized sites can be reduced by ammonia while reoxidation can be brought about by ambient oxygen, by lattice oxygen from underlying layers, or by the oxygen of NO, depending on the reaction conditions. The main objective of this study was to study the role of $\mathrm{O}_{2}$ in the reduction of NO by $\mathrm{NH}_{3}$. Attention was given to the formation of $\mathrm{N}_{2} \mathrm{O}$ and the interaction of NO with the surface during the reaction. This paper describes an investigation of the mechanism of the reduction of NO with $\mathrm{NH}_{3}$ over the catalyst series consisting of unsupported $\mathrm{V}_{2} \mathrm{O}_{5}, \mathrm{~V}_{2} \mathrm{O}_{5}$ on $\mathrm{TiO}_{2}, \mathrm{~V}_{2} \mathrm{O}_{5}$ on $\mathrm{SiO}_{3} / \mathrm{Al}_{2} \mathrm{O}_{3}$, and $\mathrm{V}_{2} \mathrm{O}_{5}$ on $\mathrm{Al}_{2} \mathrm{O}_{5}$ in the presence of ${ }^{18} \mathrm{O}_{2}$ or ${ }^{16} \mathrm{O}_{2}$ at concentration levels of about $500 \mathrm{ppm}$ for $\mathrm{NO}$ and $\mathrm{NH}_{3}$. The role of oxygen is discussed in both a qualitative and a quantitative sense.

\section{Experimental Section}

Preparation of the Catalysts. The catalysts used in this study and their main characteristics are summarized in Table I. The $\mathrm{V}_{2} \mathrm{O}_{5}$ on $\mathrm{TiO}_{2}$ monolayer catalyst (1) was prepared as described previously 15,16 by adsorption of vanadyl acetylacetonate from solution in toluene on a sample of $\mathrm{TiO}_{2}$ consisting of anatase $(68 \%$ $\mathrm{w} / \mathrm{w})$ and rutile $(32 \% \mathrm{w} / \mathrm{w})$. A sample of commercially available material (Ventron, West Germany) containing $\mathrm{V}_{2} \mathrm{O}_{5}$ on $\mathrm{SiO}_{2} /$ $\mathrm{Al}_{2} \mathrm{O}_{3}$ (2) was also examined. The catalyst $\mathrm{V}_{2} \mathrm{O}_{5}$ on $\mathrm{Al}_{2} \mathrm{O}_{5}$ (3) was made by wet impregnation of $\mathrm{Al}_{2} \mathrm{O}_{3}$ with an acidified solution ( $\mathrm{pH} \mathrm{4)} \mathrm{of} \mathrm{ammonium} \mathrm{metavanadate} \mathrm{followed} \mathrm{by} \mathrm{calcination} \mathrm{in}$ a stream of air at $450^{\circ} \mathrm{C}$. Two of the catalysts, $\mathrm{V}_{2} \mathrm{O}_{5}$ on $\mathrm{Al}_{2} \mathrm{O}_{3}$ (4) and unsupported $\mathrm{V}_{2} \mathrm{O}_{5}(5)$, were obtained from Utrecht University (The Netherlands). The powdered catalysts were pelleted, crushed, and sieved into the fraction given in Table I. Prior to the NO reduction experiments, the catalyst samples were calcined at $300-400^{\circ} \mathrm{C}$ in situ in a flow of helium containing $25 \%$ oxygen.

Characterization of the Catalysts. The vanadium contents of the catalysts were determined by using X-ray fluorescence (Philips PW 1410/20). The BET surface areas were obtained by using a Carlo Erba Sorptomatic (Type 1800) system controlled by an Apple computer system. Table I also gives the concentration of $\mathrm{V}=\mathrm{O}$ groups on the surface of each of the catalysts. This was determined according to the rectangular pulse technique, ${ }^{17}$ modified as described in ref 14 . In essence, a pulse of NO and $\mathrm{NH}_{3}$ is fed to the freshly calcined catalyst and the nitrogen resulting from the reaction

$$
6 \mathrm{NO}+4 \mathrm{NH}_{3} \rightarrow 5 \mathrm{~N}_{2}+6 \mathrm{H}_{2} \mathrm{O}
$$

is monitored. The amount of $\mathrm{N}_{2}$ formed in the initial part of the resulting pulse response is taken to represent the total number of $\mathrm{V}=\mathrm{O}$ that which are probably located at exposed (010) surfaces.

Gases. ${ }^{18} \mathrm{O}_{2}$ (isotopic purity 99 atom $\%$ ) was obtained from MSD Isotopes (Montreal, Canada) and was used without further purification. ${ }^{18} \mathrm{O}_{2}$ means ${ }^{18} \mathrm{O}{ }^{18} \mathrm{O}$. Mixtures of about $1000 \mathrm{ppm}$ ${ }^{18} \mathrm{O}_{2}$ and ${ }^{16} \mathrm{O}$, in helium at total pressures up to $10 \mathrm{MPa}$ were prepared by conventional static gravimetric methods in our laboratory. The gas mixtures of $\mathrm{NO}(2200 \mathrm{ppm})$ and of $\mathrm{NH}_{3}(2000$ ppm) in helium were purchased from Air Products and were used without further purification. The gas mixtures of $\mathrm{NO}, \mathrm{NH}_{3}$, and $\mathrm{O}_{2}$ used in the experiments were made up of the different mixtures with the aid of mass-flow controllers (Matheson).

Apparatus. The reaction system used, which is shown in Figure 1 , consists of a gas-mixing system, a reactor with oven, and a mass spectrometer; all parts were controlled and monitored by an Apple II data system. The equipment was constructed in such a way that labeled compounds could be introduced into the reactor during the selective catalytic reduction. All tubing located between the

(15) van Hengstum, A. J.; van Ommen, J. G.; Bosch, H.; Gellings, P. J. Appl. Catal. 1983, 5, 207.

(16) van Ommen, J. G.; Hoving, K.; Bosch, H.; van Hengstum, A. J.; Gellings, P. J. Z. Phys. Chem. (Frankfurt am Main) 1983, 134, 99.

(17) Miyamoto, A.; Yamazaki, Y.; Inomata, M.; Murakami, Y. J. Phys. Chem. 1981, 85, 2366.

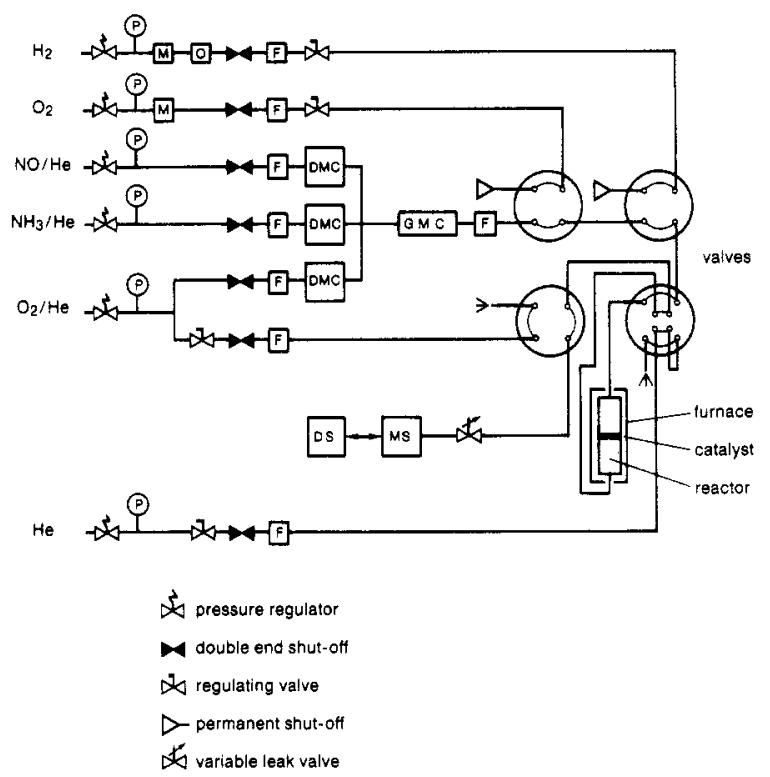

Figure 1. Apparatus used to study the reaction of $\mathrm{NO}, \mathrm{NH}_{3}$, and $\mathrm{O}_{2}$. The whole system is processed by an Apple II computer. DMC, digital mass-flow controller; DS, data system; F, in-line filter $(7 \mu \mathrm{m})$; GMC, gas-mix chamber; $M$, moisture trap; $M S$, mass spectrometer; $O$, oxygen trap; $P$, pressure gauge.

reactor and the mass spectrometer was kept at $120-140^{\circ} \mathrm{C}$ in order to avoid adsorption of the various compounds on the walls of the tubing. Neither the quartz steady-state plug-flow reactor nor the stainless steel tubing showed any catalytic activity during the experiments; in addition, no exchange was observed between the labeled compounds used and the quartz up to a temperature of $400{ }^{\circ} \mathrm{C}$. The rate of flow through the reactor (inner diameter $8 \mathrm{~mm}$ ) was about $100 \mathrm{~cm}^{3} \cdot \mathrm{min}^{-1}$ (STP). Isotopic and product analysis were performed with a magnetic mass spectrometer (Finnigan MAT 112) connected with the reactor outlet via an adjustable leak valve.

Procedures. The reaction was studied at 300,350 , and 400 ${ }^{\circ} \mathrm{C}$ over the monolayer catalyst $\mathrm{V}_{2} \mathrm{O}_{5}$ on $\mathrm{TiO}_{\mathrm{i}}$ (1) but at only 400 ${ }^{\circ} \mathrm{C}$ for the other catalysts. All experiments (except in the case mentioned in Figure 2) were carried out with $50 \mathrm{mg}$ of catalyst, with a total flow of $100 \mathrm{~cm}^{3} \cdot \mathrm{min}^{-1}$ (STP) of a gas mixture of 500 ppm of $\mathrm{NO}$ (with $21 \mathrm{ppm}$ of Ar), $500 \mathrm{ppm}$ of $\mathrm{NH}_{3}$ (with $25 \mathrm{ppm}$ of $\mathrm{Ar}$ ), and about $600 \mathrm{ppm}$ of $\mathrm{O}_{2}$, the balance being helium. The Ar was used to check the stability of the mass spectrometer during the measurements.

The transients were generated by abruptly changing, for example, the composition of the feed, from a mixture containing $\mathrm{NO} / \mathrm{NH}_{3} /{ }^{18} \mathrm{O}_{2}$ to a mixture containing $\mathrm{NO} / \mathrm{NH}_{3} /{ }^{16} \mathrm{O}_{2}$ and vice versa. The time delay from the catalyst/reactor to the mass spectrometer was determined by measuring the response curves of the various compounds (relaxation curves) in the absence of a catalyst. The time-delay values for $\mathrm{NO}, \mathrm{N}_{2} \mathrm{O}$, and $\mathrm{O}_{2}$ were 30 $\mathrm{s}$ and for $\mathrm{H}_{2} \mathrm{O}$ and $\mathrm{NH}_{3} 10$ and $30-40 \mathrm{~min}$, respectively. The gas mixture coming from the reactor was monitored on-line at regular time intervals ( $2 \mathrm{~min}$ ) with a scanning rate of 50 mass units/s; a range of $m / e=13$ up to 50 was scanned to monitor the concentrations of ammonia, nitric oxide, and oxygen and the reaction products nitrogen, nitrous oxide, water, and their isotopic isomers. ${ }^{1}$

The mass spectrometer was calibrated with known concentrations of the compounds before each measurement. The accuracy of each measurement of isotopic composition was determined by the material balance of $\mathrm{N},{ }^{16} \mathrm{O},{ }^{18} \mathrm{O}$, and $\mathrm{H}$. The mass balance of $\mathrm{N}, \mathrm{O}$, and $\mathrm{H}$ were obtained by comparing the quantities of $\mathrm{N}$, $\mathrm{O}$, and $\mathrm{H}$ introduced by the compounds $\mathrm{NO}, \mathrm{O}_{2}$, and $\mathrm{NH}_{3}$ and the quantities of $\mathrm{N}, \mathrm{O}$, and $\mathrm{H}$ present in the reaction products. The material balances were found to be in agreement up to a margin of $10 \%$, except for measurements with catalyst 1 at 350 ${ }^{\circ} \mathrm{C}$, after which strong deviations were obsered for the $\mathrm{H},{ }^{16} \mathrm{O}$, and ${ }^{18} \mathrm{O}$ balances. The detection limit for all compounds was about $1 \mathrm{ppm}$. 
TABLE II: Summary of Product Distribution (ppm) at Steady-State Conditions for NO- $\mathrm{NH}_{3}-{ }^{18} \mathrm{O}_{2}$ (Except the Concentrations of Ammonia) on Various Catalysts ${ }^{a}$

\begin{tabular}{|c|c|c|c|c|c|c|c|c|c|c|c|}
\hline catalyst no. ${ }^{b}$ & temp, ${ }^{\circ} \mathrm{C}$ & NO & ${ }^{18} \mathrm{O}_{2}$ & $\mathrm{~N}^{18} \mathrm{O}$ & $\mathrm{N}_{2}$ & $\mathrm{H}_{2} \mathrm{O}$ & $\mathrm{H}_{2}{ }^{18} \mathrm{O}$ & $\mathrm{N}_{2} \mathrm{O}$ & $\mathrm{N}_{2}{ }^{18} \mathrm{O}$ & $S_{\mathrm{N}_{2}{ }^{18} \mathrm{O}^{c}}$ & $S_{\mathrm{H}_{2}{ }^{18} \mathrm{O}^{c}}$ \\
\hline & & 500 & 455 & 0 & 0 & 0 & 0 & 0 & 0 & & \\
\hline 1 & 400 & 65 & 299 & 28 & 330 & 397 & 284 & 66 & 24 & 0.27 & 0.42 \\
\hline 1 & 350 & 82 & 351 & 17 & 370 & 579 & 177 & 20 & 4 & 0.17 & 0.23 \\
\hline \multirow[t]{2}{*}{1} & 300 & 103 & 377 & 16 & 349 & 356 & 143 & 3 & 0 & 0.00 & 0.29 \\
\hline & & 500 & 581 & 0 & 0 & 0 & 0 & 0 & 0 & & \\
\hline 2 & 400 & 188 & 520 & 45 & 245 & 342 & 111 & 19 & 4 & 0.17 & 0.15 \\
\hline 3 & 400 & 209 & 527 & 35 & 258 & 459 & 100 & 8 & 1 & 0.11 & 0.18 \\
\hline 4 & 400 & 176 & 514 & 42 & 238 & 309 & 70 & 13 & I & 0.47 & 0.18 \\
\hline 5 & 400 & 208 & 504 & 125 & 153 & 304 & 229 & 169 & 81 & 0.32 & 0.32 \\
\hline
\end{tabular}

${ }^{a}[\mathrm{NO}]_{\mathrm{i}}=\left[\mathrm{NH}_{3}\right]_{\mathrm{i}}=500 \mathrm{ppm} . \quad\left[{ }^{18} \mathrm{O}_{2}\right]_{\mathrm{i}}=455 \mathrm{ppm}$ for catalyst 1 , and for catalysts $2-5\left[{ }^{18} \mathrm{O}_{2}\right]_{\mathrm{i}}=581 \mathrm{ppm} .{ }^{b}$ See Table $\mathrm{I}$. ${ }^{c} S_{\mathrm{N}_{2}{ }^{18} \mathrm{O}}=\left[\mathrm{N}_{2}{ }^{18} \mathrm{O}\right] /$ $\left(\left[\mathrm{N}_{2} \mathrm{O}\right]+\left[\mathrm{N}_{2}{ }^{18} \mathrm{O}\right]\right) . S_{\mathrm{H}_{2}{ }^{18} \mathrm{O}}=\left[\mathrm{H}_{2}{ }^{18} \mathrm{O}\right] /\left(\left[\mathrm{H}_{2} \mathrm{O}\right]+\left[\mathrm{H}_{2}{ }^{18} \mathrm{O}\right]\right)$.

TABLE III: Components Formed or Components Reacted during the Non Steady State (0-280 min) ${ }^{a}$

\begin{tabular}{|c|c|c|c|c|c|c|c|}
\hline \multirow[b]{2}{*}{ catalyst no. ${ }^{b}$} & \multirow[b]{2}{*}{ temp, ${ }^{\circ} \mathrm{C}$} & \multicolumn{3}{|c|}{ components formed } & \multirow{2}{*}{$\begin{array}{c}{ }^{18} \mathrm{O}^{d} \\
\text { converted }\end{array}$} & \multirow{2}{*}{$\begin{array}{c}{ }^{18} \mathrm{O}^{e} \\
\text { uptake }\end{array}$} & \multirow{2}{*}{$\underset{\text { calcd }}{\mathrm{O}^{\prime}}$} \\
\hline & & $\mathrm{H}_{2}{ }^{18} \mathrm{O}^{c}$ & $\mathrm{~N}_{2}{ }^{18} \mathrm{O}^{c}$ & $\mathrm{~N}^{18} \mathrm{O}^{c}$ & & & \\
\hline 1 & 400 & 284 & 23 & 20 & 363 & 36 & 47 \\
\hline 1 & 350 & 190 & 0 & 17 & 242 & 35 & 47 \\
\hline 1 & 300 & 140 & 0 & 16 & 182 & 26 & 47 \\
\hline 2 & 400 & 86 & 4 & 38 & 142 & 14 & 137 \\
\hline 3 & 400 & 75 & 0 & 25 & 126 & 26 & 196 \\
\hline 4 & 400 & 54 & 0 & 37 & 156 & 65 & 108 \\
\hline
\end{tabular}

${ }^{a}$ Amount of catalyst, $50 \mathrm{mg}$. Quantities in micromoles. ${ }^{b}$ See Table I. ${ }^{c}$ Graphically integrated area under the curves of concentration versus time. ${ }^{d}$ Calculated from the amount of reacted oxygen (Table $\mathrm{V}$ ). ${ }^{e}$ Consumed ${ }^{18} \mathrm{O}$, which was incorporated in the catalyst during the reduction reaction of $\mathrm{NO}$ with $\mathrm{NH}_{3}$. ${ }^{f} \mathrm{Calculated}$ oxygen content for the $\mathrm{V}_{2} \mathrm{O}_{5}$ component of the catalyst.

\section{Results}

The catalysts listed in Table I were selected because of the difference in their surface area and the differences in the types of support. Table I also gives the surface concentration of $\mathrm{V}=0$ groups initially present on the catalysts. These concentrations were determined by using the pulse technique at $375^{\circ} \mathrm{C}$ for catalyst 1 and at $400^{\circ} \mathrm{C}$ for the others. Above $350^{\circ} \mathrm{C}$ the initial pulse response, which is related to the number of $\mathrm{V}=\mathrm{O}$ groups (or active sites), remains constant for any catalyst; ${ }^{18}$ the figures given in the last column of Table I can thus be compared. The value for the unsupported $\mathrm{V}_{2} \mathrm{O}_{5}$ sample is calculated from the one given in ref 17 , taking into account a specific surface area of 10.5 $\mathrm{m}^{2} \cdot \mathrm{g}^{-1}$ compared with a value of $5.4 \mathrm{~m}^{2} \cdot \mathrm{g}^{-1}$ for the sample used there.

Figure 2 shows the concentration levels of the reactants and products as a function of time over $100 \mathrm{mg}$ of the $\mathrm{V}_{2} \mathrm{O}_{5}$ on $\mathrm{TiO}_{2}$ catalyst at a temperature of $400^{\circ} \mathrm{C}$ following calcination of the catalyst at $300^{\circ} \mathrm{C}$ in a flow of $\mathrm{O}_{2}$. The concentration of a number of molecular species are plotted from the start of the reaction. The curve of $\mathrm{H}_{2} \mathrm{O}$ deviates from the profile of a step function because of adsorption of $\mathrm{H}_{2} \mathrm{O}$ on the tubing at the start of the reaction (see Experimental Section).

Significant features of the results are the abrupt decrease of the concentration of ${ }^{18} \mathrm{O}_{2}, \mathrm{NO}$, and $\mathrm{NH}_{3}$ from their initial concentrations $(455,550$, and $500 \mathrm{ppm}$, respectively), the relatively slow formation of $\mathrm{H}_{2}{ }^{18} \mathrm{O}$ and $\mathrm{N}_{2}{ }^{18} \mathrm{O}$, and the simultaneous decrease of $\mathrm{H}_{2} \mathrm{O}$. The concentration of $\mathrm{N}^{18} \mathrm{O}$, not shown for reasons of clarity, also increases, showing the same concentration profile as that of $\mathrm{H}_{2}^{18} \mathrm{O}$. The concentrations of the components, except for $\mathrm{H}_{2} \mathrm{O}, \mathrm{H}_{2}{ }^{18} \mathrm{O}, \mathrm{N}_{2} \mathrm{O}$, and $\mathrm{N}_{2}{ }^{18} \mathrm{O}$, reach a steady state within 10 min. $\mathrm{N}_{2} \mathrm{O}$ was only produced at temperatures above $300^{\circ} \mathrm{C}$. It is found that the area under the curve for $\mathrm{H}_{2}{ }^{18} \mathrm{O}$ equals the area between the curve for $\mathrm{H}_{2} \mathrm{O}$ and the dotted line shown at $720 \mathrm{ppm}$. The dotted line is the concentration of $\mathrm{H}_{2} \mathrm{O}$ at steady state when $\mathrm{O}_{2}$ is used instead of ${ }^{18} \mathrm{O}_{2}$.

Table II gives the concentrations of most of the reactants and products (except ammonia) over the catalysts under steady-state conditions for experiments such as that shown in Figure 2. In addition, the $\mathrm{V}_{2} \mathrm{O}_{5}$ on $\mathrm{TiO}_{2}$ catalyst was measured at 300 and 350 ${ }^{\circ} \mathrm{C}$. The quantity of ${ }^{18} \mathrm{O}_{2}$ consumed is seen to be largely dependent on the temperature and on the catalyst type. $\mathrm{N}_{2} \mathrm{O}$ is always produced, irrespective of the presence of labeled oxygen. In the presence of oxygen-18, $\mathrm{N}^{18} \mathrm{O}, \mathrm{H}_{2}{ }^{18} \mathrm{O}$, and $\mathrm{N}_{2}{ }^{18} \mathrm{O}$ are also found.
$(1.9 \%) \mathrm{V}_{2} \mathrm{O}_{5} / \mathrm{TiO}_{2}$

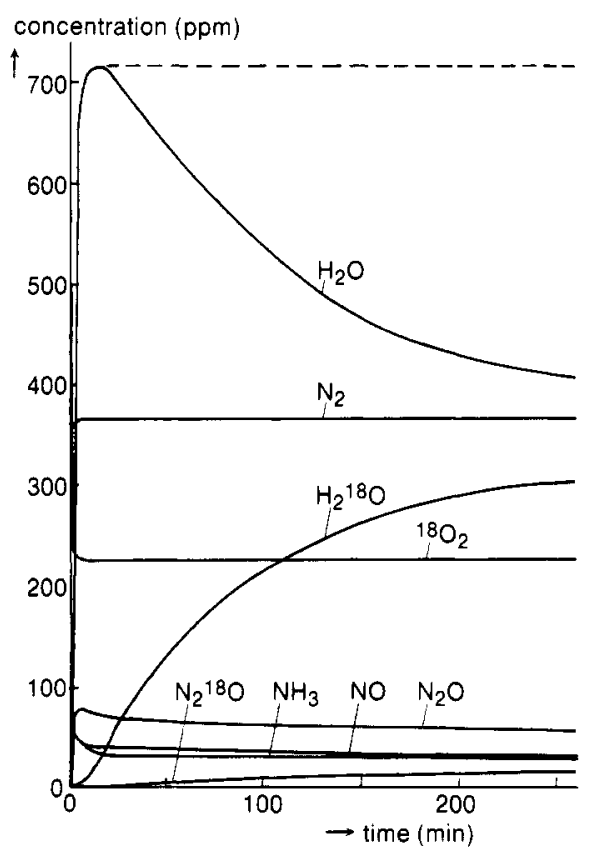

Figure 2. Concentration profiles of $\mathrm{NO}, \mathrm{NH}_{3},{ }^{18} \mathrm{O}_{2}, \mathrm{~N}_{2} \mathrm{O}$, and $\mathrm{N}_{2}{ }^{18} \mathrm{O}$ over the catalyst $\mathrm{V}_{2} \mathrm{O}_{5}$ on $\mathrm{TiO}_{2}(100 \mathrm{mg})$ at $400{ }^{\circ} \mathrm{C}$ after calcination in $\mathrm{O}_{2}$ at $400^{\circ} \mathrm{C}:[\mathrm{NO}]_{\mathrm{i}}=\left[\mathrm{NH}_{3}\right]_{\mathrm{i}}=500 \mathrm{ppm} ;\left[{ }^{18} \mathrm{O}_{2}\right]_{\mathrm{i}}=455 \mathrm{ppm}$; balance helium. The concentration of $\mathrm{N}^{18} \mathrm{O}$ has been omitted.

We found no evidence for the formation of $\mathrm{O}^{18} \mathrm{O}$ as a result of exchange of bulk oxygen of supported catalysts with ${ }^{18} \mathrm{O}_{2}$ according to the reaction

$$
{ }^{18} \mathrm{O}_{2}+\mathrm{V}=\mathrm{O} \rightarrow \mathrm{O}^{18} \mathrm{O}+\mathrm{V}={ }^{18} \mathrm{O}
$$

Hence, we conclude that this so-called scrambling ${ }^{19-21}$ process of the gaseous or adsorbed oxygen does not occur with lattice oxygen in the temperature region of $300-400^{\circ} \mathrm{C}$. In the transient isotopic tracer experiments, oxygen of the catalyst was exchanged by labeled oxygen at $400^{\circ} \mathrm{C}$ (Table III). Assuming that only the oxygen species of the vanadia part of the supported catalysts has been exchanged, it can be calculated from the figures in Table III that between 10 and $77 \%$ of the oxygen initially present in 
$(1.9 \%) \mathrm{V}_{2} \mathrm{O}_{5} / \mathrm{TiO}_{2}$

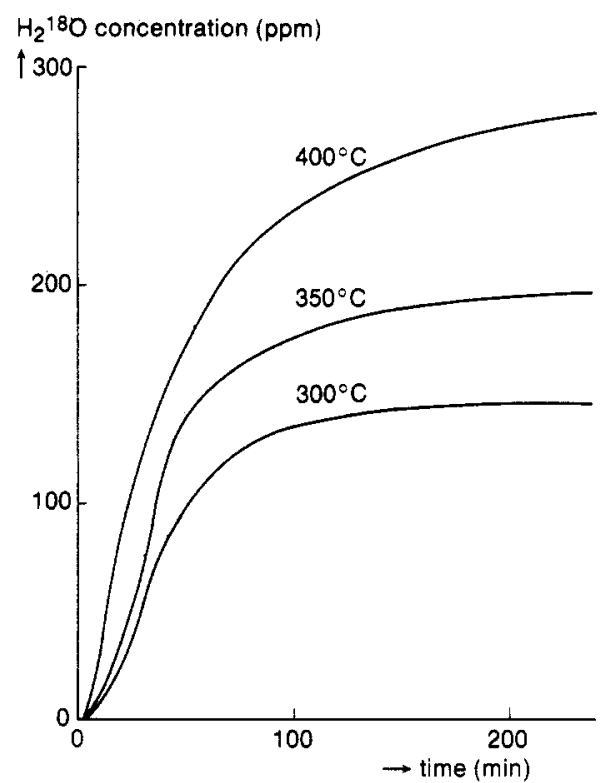

Figure 3. Concentration profiles of the reaction product $\mathrm{H}_{2}{ }^{18} \mathrm{O}$ at three temperatures for the catalyst $\mathrm{V}_{2} \mathrm{O}_{5}$ on $\mathrm{TiO}_{2}:\left[\mathrm{NO}_{\mathrm{i}}=\left[\mathrm{NH}_{3}\right]_{\mathrm{i}}=500\right.$ ppm; $\left[\mathrm{O}_{2}\right]_{\mathrm{i}}=455 \mathrm{ppm}$; balance helium. The catalysts $(50 \mathrm{mg})$, used in the separate experiments, were first calcined at $300^{\circ} \mathrm{C}$ for $1 \mathrm{~h}$ in a gas mixture of $25 \% \mathrm{O}_{2}$ in helium $\left(100 \mathrm{~cm}^{3} \cdot \mathrm{min}^{-1}\right.$ (STP)).

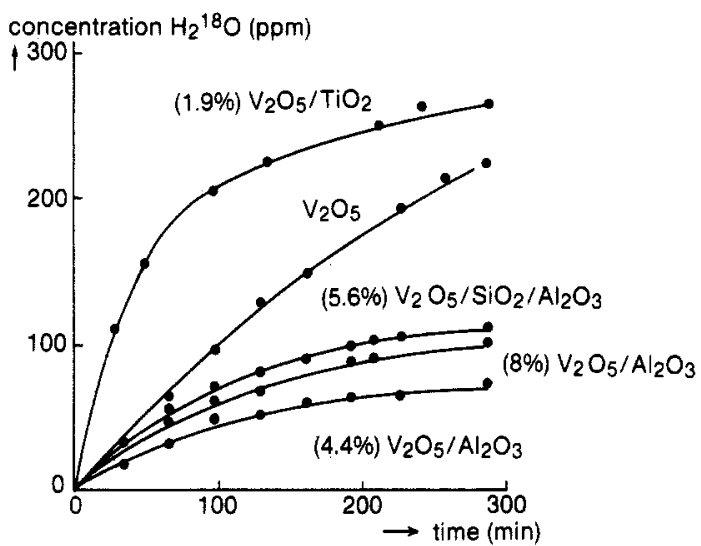

Figure 4. Concentration profiles for the various catalysts at $400{ }^{\circ} \mathrm{C}$. $[\mathrm{NO}]_{\mathrm{i}}=\left[\mathrm{NH}_{3}\right]=500 \mathrm{ppm} ;\left[{ }^{18} \mathrm{O}_{2}\right]_{\mathrm{i}}=581 \mathrm{ppm}$, except for the experiments with catalyst $\mathrm{V}_{2} \mathrm{O}_{5}$ on $\mathrm{TiO}_{2}$, where $\left[{ }^{18} \mathrm{O}_{2}\right]_{i}=455 \mathrm{ppm}$; balance helium. The catalysts were calcined at $300^{\circ} \mathrm{C}$ in a $(25 \%) \mathrm{O}_{2} / \mathrm{He}$ flow for $1 \mathrm{~h}\left(100 \mathrm{~cm}^{3} \cdot \mathrm{min}^{-1}\right.$ (STP))

the vanadia part of the catalyst can be replaced. The catalyst with the highest exchangeability of oxygen is the monolayer $\mathrm{V}_{2} \mathrm{O}_{5}$ on $\mathrm{TiO}_{2}$ (1) catalyst. The column (Table III) of ${ }^{18} \mathrm{O}$ uptake was obtained by subtracting the amount of ${ }^{18} \mathrm{O}_{2}$ consumed by the reaction of $\mathrm{NO}$ and $\mathrm{NH}_{3}$ with the total amount of ${ }^{18} \mathrm{O}$ present in the reaction products $\mathrm{H}_{2}{ }^{18} \mathrm{O}, \mathrm{N}_{2}{ }^{18} \mathrm{O}$, and ${ }^{18} \mathrm{O}_{2}$. It should be stressed that the values presented in Table III are the number of micromoles of components formed or adsorbed during the non steady state.

Figure 3 shows the effect of the temperature on the formation of $\mathrm{H}_{2}^{18} \mathrm{O}$ as a function of time in similar experiments, carried out on each occasion with a freshly calcined sample of the $\mathrm{V}_{2} \mathrm{O}_{5}$ on $\mathrm{TiO}_{2}$ catalyst. $\mathrm{H}_{2}{ }^{18} \mathrm{O}$ profiles with the other catalysts are shown in Figure 4. The catalyst with the lowest vanadia loading and the smallest specific surface area produces the most $\mathrm{H}_{2}{ }^{18} \mathrm{O}$, both in the early stages of the reaction and in the steady state. The catalyst supported on titania shows the highest initial rate of production of ${ }^{18} \mathrm{O}$-labeled water and also the highest steady-state value. The three other supported catalysts show a similar behavior at a lower level. The unsupported $\mathrm{V}_{2} \mathrm{O}_{5}$ behaves differently, rising very slowly to the steady-state level. The labeled oxygen that has
TABLE IV

\begin{tabular}{cccccc}
\hline catalyst no. ${ }^{b}$ & temp, $^{\circ} \mathrm{C}$ & TON $^{a}$ & $t_{1 / 2}, \min$ & $\tau, \mathrm{ks}$ & $\tau(\mathrm{TON})$ \\
\hline $\mathbf{1}$ & 400 & $2.3 \times 10^{-4}$ & 35 & 3.0 & 0.7 \\
$\mathbf{1}$ & 350 & $1.7 \times 10^{-4}$ & 35 & 3.0 & 0.5 \\
$\mathbf{1}$ & 300 & $1.8 \times 10^{-4}$ & 35 & 3.0 & 0.5 \\
$\mathbf{2}$ & 400 & $2.8 \times 10^{-5}$ & 73 & 6.3 & 0.2 \\
$\mathbf{3}$ & 400 & $2.1 \times 10^{-5}$ & 78 & 6.8 & 0.1 \\
$\mathbf{4}$ & 400 & $1.4 \times 10^{-5}$ & 70 & 6.1 & 0.08
\end{tabular}

${ }^{a}$ TON is the turnover number, the number of molecules of $\mathrm{H}_{2}{ }^{18} \mathrm{O}$ per site per second. $t_{1 / 2}$ is defined in the text. $\tau$ is the relaxation time, and $\tau(\mathrm{TON})$ is the number of molecules of $\mathrm{H}_{2}{ }^{18} \mathrm{O}$ per site. The surface area of one $V=0$ site is taken as $2 \times 10^{-19} \mathrm{~m}^{2}{ }^{25}{ }^{b}$ See Table I.

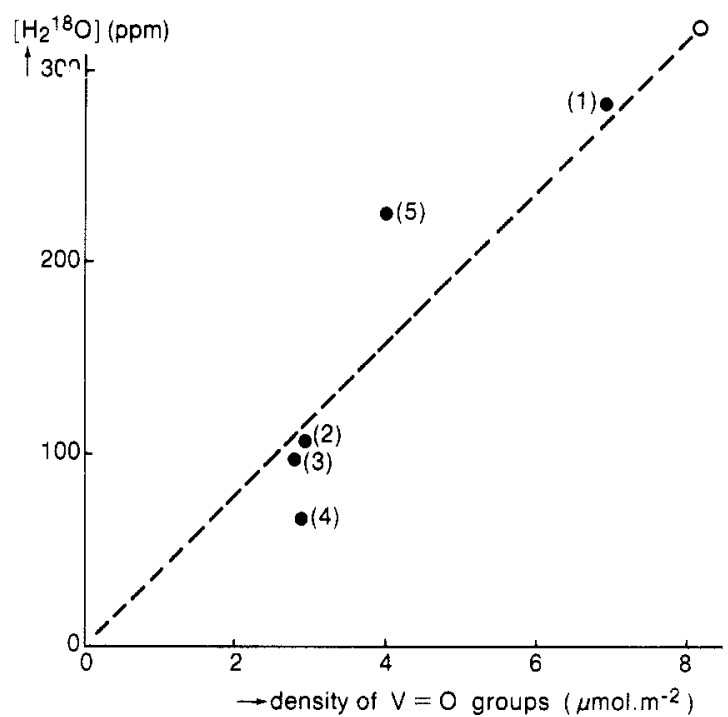

Figure 5. Relationship between the steady-state concentration of $\mathrm{H}_{2}{ }^{18} \mathrm{O}$ and the density of surface $\mathrm{V}=\mathrm{O}$ groups present in the catalysts. The maximum value for $\sigma_{\mathrm{V}-0}=2 \times 10^{-19} \mathrm{~m}^{2}$. The dotted line starts at the origin and ends at the point $\left(8.2 \mu \mathrm{mol} \cdot \mathrm{m}^{-2} ; 325 \mathrm{ppm} \mathrm{H}{ }_{2}^{18} \mathrm{O}\right)$. This point represents the maximum attainable $\mathrm{H}_{2}{ }^{18} \mathrm{O}$ concentration when the number of the $V=O$ surface groups is at a maximum.

reacted is mainly found in the $\mathrm{H}_{2}{ }^{18} \mathrm{O}$, as can be seen from the results given in Table III. The measured curves of the concentration of $\mathrm{H}_{2}{ }^{18} \mathrm{O}$ versus time shown in Figures 2,3 , and 4 can, between 15 and $110 \mathrm{~min}$, be described as exponential functions (see Discussion). The curves of $\mathrm{H}_{2}{ }^{18} \mathrm{O}$ do not fit the exponential relationship mentioned above in the first $15 \mathrm{~min}$ of the reaction. The $t_{1 / 2}$ values, defined as the time when half of the steady-state concentration of $\mathrm{H}_{2}^{18} \mathrm{O}$ has been produced in the curves of Figures 3 and 4 , are given in Table IV. The values vary between 35 and $78 \mathrm{~min}$. The $t_{1 / 2}$ time was found to be the same at each of the temperatures examined for the catalyst $\mathrm{V}_{2} \mathrm{O}_{5}$ on $\mathrm{TiO}_{2}(1)$. The relaxation time $\tau$ can be obtained by calculating $t_{1 / 2} / \ln 2$. $\tau($ TON) is a measure for the upper limit of the fractional coverage of $\mathrm{OH}$ groups (see Discussion).

The steady-state concentration of $\mathrm{H}_{2}{ }^{18} \mathrm{O}$ is plotted in Figure 5 against the density of the surface $\mathrm{V}=\mathrm{O}$ groups. The density is calculated by means of the ratio of the number of surface $V=O$ groups (determined by pulse experiments) and the total surface area (BET). A roughly linear relationship exists. (It should be noted that there is no direct proportionality between the rate of exchange to give $\mathrm{H}_{2}{ }^{18} \mathrm{O}$ and the total number of $\mathrm{V}=\mathrm{O}$ groups.) It was also observed that three groups of catalysts can be distinguished: the alumina-based catalyst, the titania-based catalyst, and pure vanadia. Both the selectivity to $\mathrm{N}_{2}{ }^{18} \mathrm{O}$ [defined as $\left.\left[\mathrm{N}_{2}{ }^{18} \mathrm{O}\right] /\left(\left[\mathrm{N}_{2}{ }^{18} \mathrm{O}\right]+\left[\mathrm{N}_{2} \mathrm{O}\right]\right)\right]$ and to $\mathrm{H}_{2}{ }^{18} \mathrm{O}$ increases with the surface density of $\mathrm{V}=\mathrm{O}$ groups (Table II). When the isotopic composition of oxygen in the feed was changed, the concentration of $\mathrm{N}_{2}{ }^{18} \mathrm{O}$ and of $\mathrm{H}_{2}^{18} \mathrm{O}$ were found to drop very rapidly, as is shown in Figure 6. The form of these curves is also exponential.

The quantities of $\mathrm{H}_{2}{ }^{18} \mathrm{O}$ (in micromoles) formed at non steady state at $400^{\circ} \mathrm{C}$ were calculated for the first 280 min by means of graphical integration of the curves of Figures 3 and 4, and the 


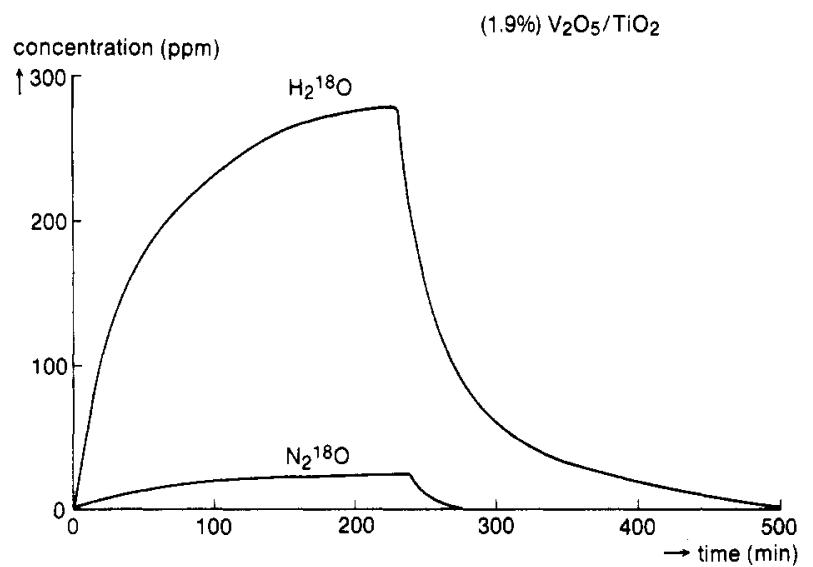

Figure 6. Transient profile of $\mathrm{H}_{2}{ }^{18} \mathrm{O}$ during the reaction of $\mathrm{NO}, \mathrm{NH}_{3}$, and oxygen. After $230 \mathrm{~min}$ the isotopic composition was abruptly changed from ${ }^{18} \mathrm{O}_{2}$ to ${ }^{16} \mathrm{O}_{2}$.

TABLE V: Apparent Reaction Rates (Atoms of Oxygen $\cdot \mathrm{m}^{-\mathbf{2}} \cdot \mathrm{h}^{-1}$ ) as a Function of Temperature of the Reaction of $\mathrm{NO}, \mathrm{NH}_{3}$, and Oxygen on the Catalyst $\mathrm{V}_{2} \mathrm{O}_{5}$ on $\mathrm{TiO}_{2}$ (1) at Different Temperatures and at 400 ${ }^{\circ} \mathrm{C}$ on Catalysts 2-5

\begin{tabular}{|c|c|c|c|c|}
\hline catalyst no. ${ }^{a}$ & temp, ${ }^{\circ} \mathrm{C}$ & $\mathrm{O}_{2}{ }^{b} \mathrm{ppm}$ & $r$ & $r_{1}^{c} \mathrm{~V}_{2} \mathrm{O}_{5}$ \\
\hline 1 & 400 & 158 & $2.1 \times 10^{19}$ & $4.8 \times 10^{19}$ \\
\hline 1 & 350 & 103 & $1.4 \times 10^{19}$ & $1.8 \times 10^{19}$ \\
\hline 1 & 300 & 77 & $1.0 \times 10^{19}$ & $0.6 \times 10^{19}$ \\
\hline 2 & 400 & 61 & $0.8 \times 10^{19}$ & \\
\hline 3 & 400 & 53 & $0.7 \times 10^{19}$ & \\
\hline 4 & 400 & 67 & $0.9 \times 10^{19}$ & \\
\hline 5 & 400 & 77 & $1.0 \times 10^{19}$ & \\
\hline
\end{tabular}

${ }^{a}$ See Table I. ${ }^{b} \mathrm{O}_{2}$ consumption in the steady state. ${ }^{c}$ Calculated from data of ref 29.

results are given in Table III. It turns out that the consumption of oxygen -18 by the catalyst surface at $400^{\circ} \mathrm{C}$ varies between 10 and $77 \%$ of the oxygen present in the vanadia of the catalyst (Table III) and that although this amount is dependent on the reaction temperature, it is always less than the calculated quantity of oxygen in the $\mathrm{V}_{2} \mathrm{O}_{5}$ of the catalyst.

From the oxygen- 18 consumed by the catalyst and the specific surface area, an apparent reaction rate, defined as the number of atoms of oxygen reacting in the steady state per unit-specific surface area per hour, can be calculated (Table V). The apparent rates of reaction of oxygen-18 for the catalyst $\mathrm{V}_{2} \mathrm{O}_{5}$ on $\mathrm{TiO}_{2}(1)$ are comparable with those of vanadia. Hence the behavior of $\mathrm{V}_{2} \mathrm{O}_{5}$ on $\mathrm{TiO}_{2}(1)$ and unsupported $\mathrm{V}_{2} \mathrm{O}_{5}$ are about the same with respect to the consumption of oxygen.

In order to find the answer to the question whether ${ }^{18} \mathrm{O}$ remains present in the catalyst or not, ${ }^{18} \mathrm{O}$ was introduced into the catalyst at $400{ }^{\circ} \mathrm{C}$. This resulted in a labeled catalyst. This was done by pretreating the monolayer catalyst first with a gas mixture of $\mathrm{NO}, \mathrm{NH}_{3}$, and ${ }^{18} \mathrm{O}_{2}$ at $400{ }^{\circ} \mathrm{C}$. The catalyst was then kept in helium at $400^{\circ} \mathrm{C}$ for $15 \mathrm{~h}$. According to Table III the monolayer catalyst had adsorbed $36 \mu \mathrm{mol}$ of ${ }^{18} \mathrm{O}$ at $400{ }^{\circ} \mathrm{C}$. This value corresponds to the difference between the total amount of ${ }^{18} \mathrm{O}$ that was consumed by the reaction and the total amount of ${ }^{18} \mathrm{O}$ present in the products $\mathrm{H}_{2}{ }^{18} \mathrm{O}, \mathrm{N}_{2}{ }^{18} \mathrm{O}$, and $\mathrm{N}^{18} \mathrm{O}$. Figure 7 shows the result of a reaction of $\mathrm{NO}, \mathrm{NH}_{3}$, and $\mathrm{O}_{2}$ over the labeled $\mathrm{V}_{2} \mathrm{O}_{5}$ on $\mathrm{TiO}_{2}$ catalyst. The integrated area of the peak of Figure 7 corresponds to $17.5 \mu \mathrm{mol}$ of ${ }^{18} \mathrm{O}$. Hence, $18.5 \mu \mathrm{mol}$ of ${ }^{18} \mathrm{O}$ of that had been added to the surface during the $\mathrm{NO} / \mathrm{NH}_{3} /{ }^{18} \mathrm{O}_{2}$ reaction and was then removed after the catalyst was flushed with helium at 400 ${ }^{\circ} \mathrm{C}$ overnight, before the reaction with the mixture containing $\mathrm{O}_{2}$ was carried out.

\section{Discussion}

Role of Oxygen at the Surface of the Catalyst. The extended mechanism is shown in Figure 8 . Reaction 4 has already been discussed in the literature, and it was shown by Miyamoto et al. ${ }^{17}$ that the $\mathrm{V}=\mathrm{O}$ species of supported vanadia catalysts plays an
$(1.9 \%) \mathrm{V}_{2} \mathrm{O}_{5} / \mathrm{TiO}_{2}$

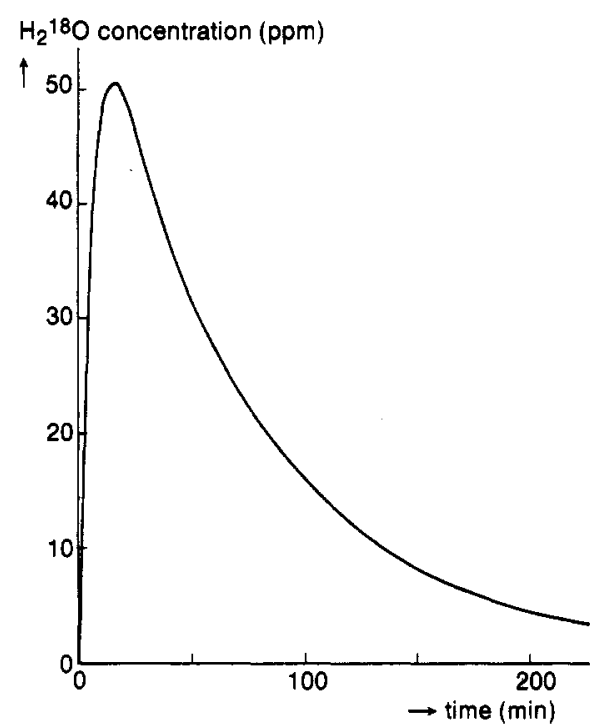

Figure 7. Concentration profile of $\mathrm{H}_{2}{ }^{18} \mathrm{O}$ when the feed is changed from $\mathrm{NO}, \mathrm{NH}_{3}$, and ${ }^{18} \mathrm{O}_{2}$ to helium at $400^{\circ} \mathrm{C}$ for $15 \mathrm{~h}$ and then changed abruptly to $\mathrm{NO}, \mathrm{NH}_{3}$, and ${ }^{16} \mathrm{O}_{2}$.

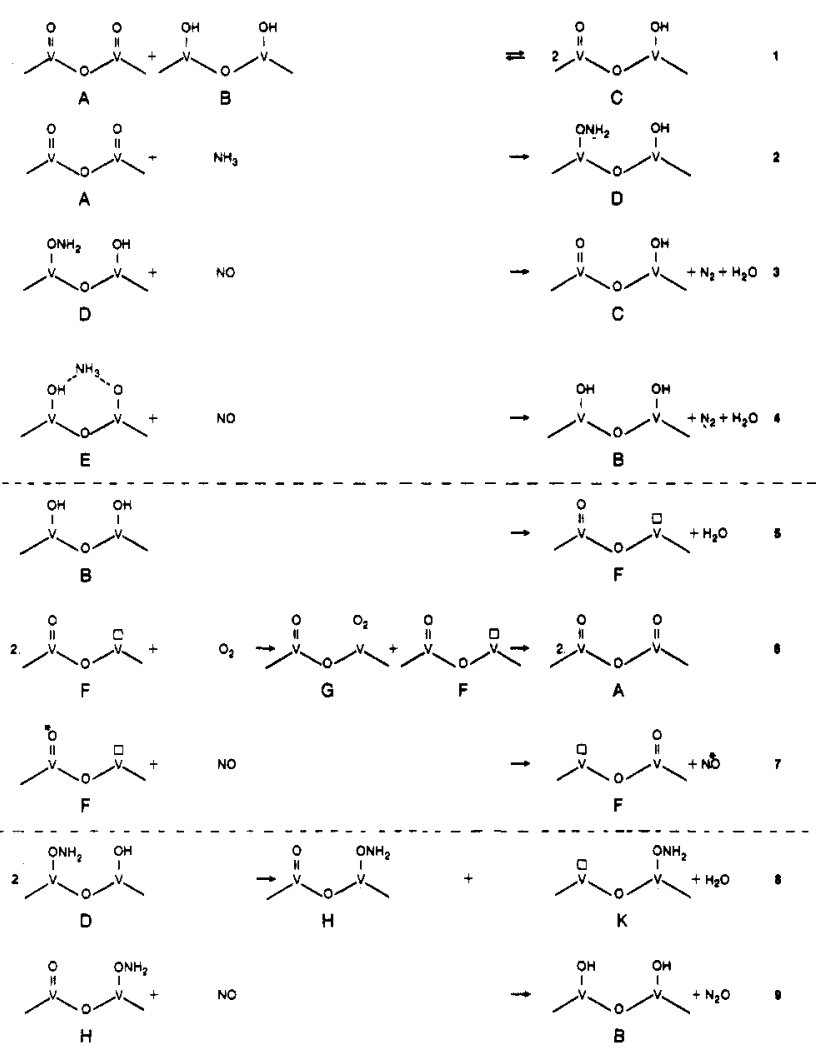

Figure 8. Mechanism for the reaction of $\mathrm{NO}, \mathrm{NH}_{3}$, and $\mathrm{O}_{2}$ on a supported vanadia catalyst and formation of $\mathrm{N}_{2}$ and $\mathrm{H}_{2} \mathrm{O}$ via an Eley-Rideal reaction.

important role in the selective catalytic reduction of NO with ammonia both in the presence and in the absence of gaseous oxygen (step 4 in Figure 8). The rate of the reaction is markedly enhanced by gas-phase oxygen. ${ }^{1-4} \mathrm{~V}=\mathrm{O}$ was identified by various techniques as the active surface site. ${ }^{3,5,17}$ In the proposed mechanism, ${ }^{17} \mathrm{~V}=\mathrm{O}$ is reduced to $\mathrm{V}-\mathrm{OH}$, which is then reoxidized by gaseous oxygen or oxygen from the underlying layers. However, only indirect evidence has been given for the existence of $\mathrm{V}-\mathrm{OH}$ groups during the reaction, and the role of oxygen as an accelerator of the reduction of $\mathrm{NO}$ by $\mathrm{NH}_{3}$ has still not been established. A modified mechanism was put forward in a previous paper, ${ }^{14}$ in which it was concluded that oxygen from the underlying layers in monolayer catalysts does not play an important role in 
the overall reaction. In the following discussion a modified and extended reaction mechanism is proposed in which light is thrown on the role of oxygen.

At the start of the reaction, and probably also during its course, three combinations of the groups $\mathrm{V}=\mathrm{O}$ and $\mathrm{V}-\mathrm{OH}, \mathrm{A}, \mathrm{B}$, and $C$, can be thought of as being present on the surface of the catalyst. Due to the mobility of the protons of the $\mathrm{OH}$ groups, these species are in equilibrium according to reaction 1 (Figure 8). Species $B$ can be considered as the hydrogenated form of species $A$ and C. We assume that the number of species $A$ in an oxygen-rich atmosphere is greater than that of species B and C. Ammonia is assumed to adsorb differently on species $A$ and $C$. (i) It may be dissociatively adsorbed on species $\mathrm{A}$ according to reaction 2 (Figure 8), a step that involves breaking of the $\mathrm{N}-\mathrm{H}$ bond in ammonia; two $\mathrm{V}=\mathrm{O}$ groups are reduced by one ammonia molecule to form species $\mathrm{D}$. This complex $\mathrm{D}$ may react with NO via an Eley-Rideal mechanism, reforming species $\mathrm{C}$ as shown reaction 3 of Figure 8. (ii) Alternatively, ammonia may adsorb physically on species $\mathrm{C}$ a Brønsted site, ${ }^{3,5,19-21}$ and the species $\mathrm{E}$ formed can then again react with NO according to an Eley-Rideal mechanism (reaction 4). This step also appears in the mechanism proposed by Miyamoto et al. ${ }^{5}$ Both the chemisorbed ammonia species $\mathrm{D}$ and the physisorbed ammonia species $\mathrm{E}$ are thus able to react with nitric oxide via an Eley-Rideal mechanism, resulting in the formation of species $C$ and $B$, respectively, water and nitrogen being formed in both cases. Water formed in this way would contain oxygen from the nitric oxide, assuming that the $\mathrm{V}-\mathrm{O}$ bonds at the surface remain intact.

The next step in the mechanism, reaction 5 , is dehydration of the surface, creating an oxygen vacancy (VD). Here oxygen from the surface is used. Thus, during the allover reaction of the catalytic reduction of NO, two types of water are formed: that originating from the reaction of gaseous $\mathrm{NO}$ with adsorbed $\mathrm{NH}_{3}$ (reactions 3 and 4 ) and that formed as a result of the dehydration of $\mathrm{OH}$ groups present on the surface of the catalyst (reaction 5). The latter reaction is relatively slow compared with the former, which can be concluded from the shape of the curves of $\mathrm{H}_{2}{ }^{18} \mathrm{O}$ in Figures 2 and 3 in the first $15 \mathrm{~min}$ of the reaction. Evidence for the dehydration is obtained when ${ }^{18} \mathrm{O}_{2}$ is used instead of ${ }^{16} \mathrm{O}_{2}$. As can be seen in Figure 2, the oxygen concentration drops immediately and remains constant during the course of the reaction; however, the rate of formation of $\mathrm{H}_{2}{ }^{18} \mathrm{O}$ is relatively slow compared with the rate of decrease of ${ }^{18} \mathrm{O}_{2}$. A possible explanation for this behavior is that the molecular oxygen initially adsorbed during the reaction does so on a single site, as shown in reaction 6 of Figure 8 . When a vacancy arises next to the adsorbed oxygen molecule, the molecule dissociates and one of the atoms becomes adsorbed on the vacancy, with the other remaining on the original site. Oxygen can thus enter into the catalyst surface in a single step. This phenomenon was already observed by Hirota et al. ${ }^{22}$ in the case of the oxidation of carbon monoxide over a $\mathrm{V}_{2} \mathrm{O}_{5}$ catalyst; the role of gaseous oxygen here was to replenish the lattice oxygen consumed by the reaction with $\mathrm{CO}$.

At the beginning of the reaction, the necessary pairs or clusters of vacancies are provided by the equilibrium oxygen-deficient state of the oxide and the oxygen vacancies created by the reduction of $\mathrm{NO}$ with $\mathrm{NH}_{3}$. Supported $\mathrm{V}_{2} \mathrm{O}_{5}$ and unsupported $\mathrm{V}_{2} \mathrm{O}_{5}$ catalysts contain many defects (oxygen vacancies) on the surface. As the reaction in the presence of oxygen continues, there are few vacancies left on the surface because every vacancy is immediately occupied by one oxygen molecule. The rate-determining step in the reaction is thus the dehydration of the surface, and the oxygen of the surface is involved in the formation of water.

(18) Oldenziel, J. Internal Report, April 1986; Twente University of Technology.

(19) Takagi, M.; Kawai, T.; Soma, M.; Onishi, T.; Tamaru, K. J. Phys. Chem. 1976, 4, 430.

(20) Takagi-Kawai, M.; Soma, M.; Onisihi, T.; Tamaru, K. Can. J. Chem $1980,58,2132$.

(21) Willey, R. J.; Eldridge, J. W.; Kittrell, J. R. Ind. Eng. Chem. Prod. Res. Dev. 1985, 24, 226.

(22) Hirota, K.; Kera, Y.; Teratani, S. J. Phys. Chem. 1968, 72, 3133.
One of the types of surface groups present during the course of the reaction is $\mathrm{V}-\mathrm{OH}$, and the question still remaining is what the number of these groups on the working catalyst is. The relaxation curves shown in Figures 3 and 4 can be used to calculate an upper limit for this number according to the procedures described by Biloen et al.;3 the results are given in Table IV. Biloen and co-workers have used such transient behavior in experiments on methanation and Fisher-Tropsch catalysis ${ }^{23,24}$ in order to obtain transient kinetic information without disturbing the steady-state situation. They showed that the response (or relaxation) time $\tau$, the coverage in surface intermediates $\theta_{i}$ (defined as the ratio of the number of surface intermediates and the number of surface-exposed catalyst atoms), and the turnover number, under certain restrictions, are related:

$$
\mathrm{TON}=\theta_{\mathrm{i}} \tau
$$

This relationship will now be discussed briefly. Suppose that an arbitrary area of the catalyst surface, containing $N_{\mathrm{s}}$ surface oxygen atoms, is covered with a pool of $N_{\mathrm{i}} \mathrm{OH}$ groups (the sum of the number of ${ }^{18} \mathrm{OH}$ and ${ }^{16} \mathrm{OH}$ groups) and produces $R \mathrm{H}_{2}{ }^{18} \mathrm{O}$ molecules per second under steady-state conditions. The relation between time and the pool's isotopic composition, which is related to the ratio of the number of ${ }^{18} \mathrm{OH}$ groups and the total number of $\mathrm{OH}$ groups present on the surface, can be then described by

$$
F(t)=1-e^{-t / \tau}
$$

where $t$ is the time and

$$
\tau=N_{\mathrm{i}} / R=t_{1 / 2} / \ln 2
$$

$N_{\mathrm{i}} / R$ can also be written as $\left(N_{\mathrm{i}} / N_{\mathrm{s}}\right) /(R / N)=\theta_{\mathrm{i}} /$ TON. The relaxation curves, shown in Figures 3 and 4 , are almost purely exponential between 15 and $110 \mathrm{~min}$ and may be characterized by an exponential equation of the form

$$
F(t)=1-e^{-t / t}
$$

where $F(t)=\left[\mathrm{H}_{2}{ }^{18} \mathrm{O}\right] /\left[\mathrm{H}_{2}{ }^{18} \mathrm{O}\right]_{\infty},\left[\mathrm{H}_{2}{ }^{18} \mathrm{O}\right]_{\infty}$ being the concentration of $\mathrm{H}_{2}{ }^{18} \mathrm{O}$ in the steady state and inversely proportional to the reciprocal pseudo-first-order rate constant. The $\tau$ values can thus be converted into the $\theta_{\mathrm{i}}$ values, given in Table IV. The $t_{1 / 2}$ values are constant at different temperatures. At $400^{\circ} \mathrm{C}$ the maximum coverage of the surface with $\mathrm{OH}$ groups is about 0.7 for the catalyst $\mathrm{V}_{2} \mathrm{O}_{5}$ on $\mathrm{TiO}_{2}$ (1) (Table IV) and has the value of 0.5 at 350 and $300{ }^{\circ} \mathrm{C}$. This maximum coverage decreases as the specific surface area increases and as the number of active sites, represented by the number of $\mathrm{V}=\mathrm{O}$ groups per gram of catalyst, increases.

The activities of the $\mathrm{V}_{2} \mathrm{O}_{5}$ on $\mathrm{TiO}_{2}$ and $\mathrm{V}_{2} \mathrm{O}_{5}$ on $\mathrm{SiO}_{2} / \mathrm{Al}_{2} \mathrm{O}_{3}$ catalysts and the $\mathrm{V}_{2} \mathrm{O}_{5}$ on $\mathrm{Al}_{2} \mathrm{O}_{3}$ and the unsupported $\mathrm{V}_{2} \mathrm{O}_{5}$ catalysts are $80-90 \%$ and $58-65 \%$, respectively, suggesting that the number of active sites is almost the same for each of the two groups of catalysts. Thus, at constant activity, both the selectivity of $\mathrm{H}_{2}{ }^{18} \mathrm{O}$ to $\mathrm{H}_{2} \mathrm{O}$ and the maximum coverage of the surface with $\mathrm{OH}$ groups decrease (Table II). However, the ${ }^{18} \mathrm{O}$ consumption of the surface increases with increasing specific surface area and vanadium content of the catalysts. This leads to two conclusions: (i) the surface is covered with $\mathrm{OH}$ groups which are distributed randomly; and (ii) the number of adjacent $\mathrm{OH}$ groups decreases with increasing surface area. For the formation of gaseous water from two $\mathrm{OH}$ groups on the surface (reaction 5 of Figure 8), it is necessary that these $\mathrm{OH}$ groups are adjacent. As the reaction proceeds, two or more adjacent $\mathrm{OH}$ groups are produced when ammonia reacts with gaseous nitric oxide (reaction 4). This dual-site mechanism is illustrated by the results of Figure 5, where the concentration of $\mathrm{H}_{2}{ }^{18} \mathrm{O}$ formed in the steady state is plotted as a function of the "density" of the $\mathrm{V}=\mathrm{O}$ groups. This relationship demonstrates the statistical character of the process: the higher the density of $\mathrm{V}=\mathrm{O}$ groups, the higher the number of adjacent sites. From the number of $\mathrm{V}=\mathrm{O}$ groups on the surface

(23) Biloen, P.; Helle, J. N.; van den Berg, F. G. A.; Sachtler, W. M. H. J. Catal. 1983, $81,450$.

(24) Happel, J. Chem. Eng. Sci. 1978, 33, 1567. 
<smiles>C[V](O)OI(C)O</smiles><smiles>C[Y](=O)O[V](=O)[C@H](CO[N+](=O)[O-])[N+](=O)[O-]</smiles><smiles>COC[C@@H](N)[C@@H](N)C=O</smiles><smiles>C[V](O)O[V](C)O</smiles>

Figure 9. Summarized reaction mechanism of the selective catalytic reduction of $\mathrm{NO}$ with $\mathrm{NH}_{3}$ in the presence of oxygen.

and the specific surface area, the surface density was calculated. The rate of $\mathrm{H}_{2}{ }^{18} \mathrm{O}$ exchange is thus related to the density of surface $\mathrm{V}=\mathrm{O}$ groups. In a similar way the turnover numbers calculated from the dynamic exchange experiments are also related to the density of $\mathrm{V}=\mathrm{O}$ species shown in Figure 3.

The plot in Figure 5 may reflect the specific exposure of (010) crystal planes as the only planes containing $\mathrm{V}=\mathrm{O}$ groups. It was shown by Miyamoto et al. ${ }^{17}$ that about $50 \%$ of the surface area of unsupported $\mathrm{V}_{2} \mathrm{O}_{5}$ consists of (010) planes. It is significant that the maximum density of $\mathrm{V}=\mathrm{O}$ species which could be accommodated on the vanadium-titanium monolayer material, assuming that the whole surface is covered by $\mathrm{V}=0$ groups, is $8.2 \mu \mathrm{mol} \cdot \mathrm{m}^{-2} ; 80 \%$ of this is achieved (see Figure 5 ). This is probably due to the perfect fit of the (010) planes of $\mathrm{V}_{2} \mathrm{O}_{5}$ to the planes of anatase, as has been shown by Vejux and Courtine. ${ }^{26}$ It is recognized ${ }^{25,27}$ that such a monolayer does not possess the structure of pure $\mathrm{V}_{2} \mathrm{O}_{5}$. In contrast to the results for the titania-supported materials, alumina and alumina/silica carriers do not offer such an epitaxial fit, and the supported $\mathrm{V}_{2} \mathrm{O}_{5}$ exposes fewer $(010)$ planes, and hence fewer active sites, than unsupported $\mathrm{V}_{2} \mathrm{O}_{5}$.

In Figure 9 a reaction mechanism is proposed; this involves a series of steps giving rise to reduction and reoxidation of the surface. Each of the steps represents a combination of the reactions shown in the scheme of Figure 8.

Role of Oxygen in the Catalyst. It is assumed that integration of the curve between 230 and $500 \mathrm{~min}$ in Figure 6 represents the maximum amount (about $47 \mu \mathrm{mol}$; see Table III) of the exchangeable oxygen present in the catalyst. However, when the feed was not instantly changed but the catalyst was first flushed in helium for $15 \mathrm{~h}$, half of the amount of ${ }^{18} \mathrm{O}$ previously adsorbed by the catalyst had disappeared or was not available for reaction with the $\mathrm{NO}$ and $\mathrm{NH}_{3}$ mixture. We suggest that the oxygen-18 had diffused into the support of the catalyst via oxygen vacancies and that oxygen-16 had diffused in the opposite direction. This process is relatively slow. The exchange experiments in general showed that ${ }^{18} \mathrm{O}$ is readily incorporated into the reaction product water and that ${ }^{18} \mathrm{O}$, present on the surface, can easily be replaced by ${ }^{16} \mathrm{O}$. The presence of exchangeable oxygen in vanadium pentoxide, particularly the oxygen of the $\mathrm{V}=\mathrm{O}$ groups, has

(25) Bond, G. C.; Zurita, J. P.; Flamersz, S.; Gellings, P. J.; Bosch, H.; van Ommen, J. G.; Kip, B. J. Appl. Catal. 1986, 22, 361 .

(26) Vejux, A.; Courtine, P. J. Solid State Chem. 1978, 23, 93.

(27) Kozlowsky, R.; Pettiferond, R. F.; Thomas, J. M. J. Phys. Chem. $1983,87,5176$. previously been shown by using an infrared technique..$^{28} \quad \mathrm{WO}_{3}$, $\mathrm{MoO}_{3}$, and $\mathrm{V}_{2} \mathrm{O}_{5}$ have been reported to exchange the whole of their lattice oxygen with the gas phase, the diffusion of oxygen through the solid being faster than the surface exchange, which is therefore rate determining. ${ }^{29-31}$ Rates of about $10^{18}$ atoms. $\mathrm{m}^{-2} \cdot \mathrm{h}^{-1}$ at temperatures in the range of $553-747^{\circ} \mathrm{C}$ have been mentioned in the literature. ${ }^{31}$ This extraordinarily high reactivity and lability of the bulk oxygen of the oxides is explained in terms of structural defects in the bulk: ${ }^{31}$ distorted octahedra connected with each other along common edges or corners. $\mathrm{N}^{18} \mathrm{O}$ is formed during the reaction, and we therefore conclude that NO is dissociatively adsorbed on the surface in such a way that the oxygen species can be exchanged according to reaction 7 (Figure 8). A study about the formation of $\mathrm{N}^{18} \mathrm{O}$ will be presented in a forthcoming paper.

Formation of $\mathrm{N}_{2} \mathrm{O}$. The reaction mechanism presented above is not complete. One of the questions left is how and on what type of site $\mathrm{N}_{2}$ and $\mathrm{N}_{2} \mathrm{O}$ are formed. From the literature, it is well-known that both this $\mathrm{N}_{2}$ and this $\mathrm{N}_{2} \mathrm{O}$ are produced from one nitrogen atom of the $\mathrm{NH}_{3}$ and that from the $\mathrm{NO},{ }^{5,7,8}$ but the nature of the site or sites on which these reactions take place is not known. The formation of $\mathrm{N}_{2} \mathrm{O}$ can be explained by reaction 9 in Figure 8. NO reacts with species $\mathrm{H}$, and at the same time two $\mathrm{V}=\mathrm{O}$ groups are reduced to $\mathrm{V}-\mathrm{OH}$ groups; species $\mathrm{H}$ can be formed through a reaction such as step 8 (Figure 8).

Another possibility is that a vacancy of the type associated with species $F$ can be reoxidized with gaseous oxygen or with nitric oxide. In the reoxidation by $\mathrm{NO}$, this molecule adsorbs on an oxygen vacancy. If two vacancies are formed side by side, $\mathrm{N}_{2} \mathrm{O}$ can be produced directly, leaving one oxygen atom on the vacancy, and species $F$ is regenerated. In a forthcoming paper we will discuss the role of ammonia in the mechanism and the cause of nitrous oxide formation during the reaction of $\mathrm{NO}$ and $\mathrm{NH}_{3}{ }^{32}$

\section{Conclusions}

Oxygen atoms from both lattice and NO participate in the formation of water and nitrous oxide. A more detailed mechanism based on the experimental results with nitrogen and oxygen tracers has been proposed for the reaction of $\mathrm{NO}$ with $\mathrm{NH}_{3}$ in the presence of oxygen. All the phenomena observed could be explained in terms of the proposed mechanism. Oxygen atoms of vanadia participate in the reaction of nitric oxide and ammonia and are exchanged during the reaction with gaseous oxygen. We have been able to establish that the process involving displacement of oxygen from the surface is not accompanied by isotopic scrambling, which suggests that $\mathrm{O}_{2}$ is adsorbed by the catalyst as molecular oxygen. The formation of $\mathrm{N}^{18} \mathrm{O}$ can be explained by assuming scrambling of $\mathrm{NO}$ with $\mathrm{V}={ }^{18} \mathrm{O}$ groups.

Acknowledgment. We thank Prof. John Geus (Utrecht University, The Netherlands) for providing the $\mathrm{V}_{2} \mathrm{O}_{5}$ on $\mathrm{Al}_{2} \mathrm{O}_{3}$ catalyst and the unsupported $\mathrm{V}_{2} \mathrm{O}_{5}$ catalyst.

Registry No. NO, 10102-43-9; $\mathrm{NH}_{3}, 7664-41-7 ; \mathrm{O}_{2}, 7782-44-7 ; \mathrm{V}_{2} \mathrm{O}_{5}$, 1314-62-1; $\mathrm{TiO}_{2}, 13463-67-7$.

(28) Kera, Y.; Teratani, S.; Hirota, K. Bull. Chem. Soc. Jpn. 1967, 40, 2458.

(29) Boreskov, G. K. Adv. Catal. 1964, 15, 285

(30) Novakova, J.; Klier, K.; Jiru, P. Reactivity of Solids; Schwab, G., Ed.; Elsevier: Amsterdam, 1965; p 269.

(31) Winter, E. R. S. J. Chem. Soc. A 1968, 2889.

(32) Janssen, F.; Ross, J. H. R., unpublished results. 